Foss. Rec., 21, 207-212, 2018

https://doi.org/10.5194/fr-21-207-2018

(C) Author(s) 2018. This work is distributed under

the Creative Commons Attribution 4.0 License.

\title{
A new genus of fungus weevils (Coleoptera: Anthribidae) in Rovno amber
}

\author{
Andrei A. Legalov ${ }^{1,2}$, Vitaliy Y. Nazarenko ${ }^{3}$, and Evgeny E. Perkovsky ${ }^{3}$ \\ ${ }^{1}$ Institute of Systematics and Ecology of Animals, Siberian Branch, Russian Academy of Sciences, Frunze Street 11, \\ Novosibirsk 630091, Russia \\ ${ }^{2}$ Altai State University, Lenina, 61, Barnaul 656049, Russia \\ ${ }^{3}$ Schmalhausen Institute of Zoology, National Academy of Sciences of Ukraine, B. Khmel'nyts'koho 15, \\ Kiev 01601, Ukraine
}

Correspondence: Andrei A. Legalov (fossilweevils@gmail.com)

Received: 13 June 2018 - Revised: 26 July 2018 - Accepted: 4 August 2018 - Published: 21 August 2018

\begin{abstract}
New fungus weevils, Eduardoxenus unicus (ZooBank registration: urn:lsid:zoobank.org:act:5732 BC859148-4FE5-A4F6-46847BA0138D, urn:lsid:zoobank.org: act:4D3B3EA8-AE0E-4E6D-A770-B427AC19ED03)

Legalov, Nazarenko et Perkovsky, gen. et sp. nov. (Coleoptera: Anthribidae), are described from late Eocene Rovno amber. The new genus is similar to the genus Cyptoxenus Valentine, 1982, but differs in coarsely faceted eyes, antennomere 2 shorter than antennomere 1 and an almost glabrous body. It differs from the genus Valenfriesia Alonso-Zarazaga et Lyal, 1999 in the coarsely faceted eyes, almost straight transversal carina on the pronotum and distinct elytral humeri, and it differs from the genus Neoxenus Valentine, 1999 in distinct lateral carina on the pronotum, coarsely faceted eyes and almost straight transversal pronotal carina. This fossil fungus weevil is the oldest finding of the tribe Valenfriesiini in fossil state and the first record of the Choraginae from the Eocene amber. The palaeogeographical and palaeoclimatological importance of finding Valenfriesiini in Rovno amber is discussed.
\end{abstract}

\section{Introduction}

Fungus weevils are a very diverse group of primitive weevils closely related to the family Nemonychidae and adapted to development in rotting wood or in seeds. More than 3800 species in more than 380 genera are known (Rheinheimer, 2004; Mermudes and Leschen, 2014). The oldest Anthribidae, the extinct Juranthribinae and Protoscelinae, date from the border of the Middle and Upper Jurassic (Legalov, 2011, 2013b). Urodontinae is the isolated extant subfamily with a centre of diversity in South Africa but is also distributed in tropical Africa, North Africa and Eurasia (Louw, 1993). An un-described species of this subfamily is recorded from the Eocene Baltic amber (Hieke and Pietrzeniuk, 1984). Most species and supraspecific taxa of Anthribidae belong to the subfamily Anthribinae, which is recorded from the middle Cretaceous of the Russian Far East (Zherikhin, 1993; Legalov, 2013b; Nadein and Perkovsky, 2018). The Choraginae subfamily is widely distributed throughout the world but is much poorer in species. The earliest find of the Choraginae is known from the Early Cretaceous of Spain (Soriano et al., 2006). Several species of this subfamily were described from the Miocene Dominican amber (Poinar Jr. and Legalov, 2016). The Choraginae were not known earlier from the Eocene European amber (Legalov, 2015). In this paper, we describe a new genus with a new species belonging to the tribe Valenfriesiini.

\section{Material and methods}

The specimen was obtained from quarry "Pugach" (Klesov, Rovno region) (Perkovsky et al., 2010); the amber sample was small (1.1 g after primary treatment); no syninclusions were found. Rovno amber (Late Eocene) comprises succinite, as well as famous Baltic amber (Perkovsky et al., 2010; Belles and Perkovsky, 2016). The botanical origin of succinite is highly controversial (Seyfullah et al., 2018). 

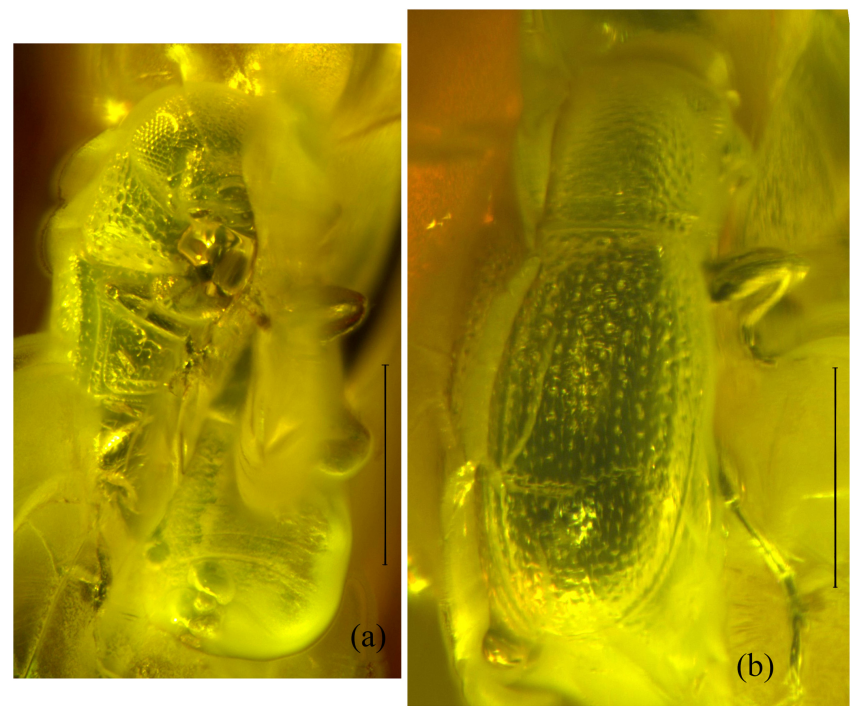

Figure 1. Eduardoxenus unicus gen. et sp. nov.: (a) body, ventral view; (b) body, dorsal view. $\mathrm{Bar}=0.5 \mathrm{~mm}$.

The amber piece with inclusion is deposited in the Schmalhausen Institute of Zoology of the National Academy of Sciences of Ukraine, Kiev (SIZK), amber collection.

The morphological terminology used in this paper follows Lawrence et al. (2010).

\section{Systematic paleontology}

Family Anthribidae Billberg, 1820

Subfamily Choraginae W. Kirby, 1819

Tribe Valenfriesiini Alonso-Zarazaga et Lyal, 1999

Genus Eduardoxenus gen. nov.

Type species Eduardoxenus unicus sp. nov.

Etymology: The genus is named after the father of the last author.

Diagnosis: Body is almost glabrous; rostrum short, without carina; labrum free; mandibles longer than rostrum; rostral pleurostomal sinus deep; eyes large, coarsely faceted; antennal scrobes foveiform; antennae inserted anterodorsally, not geniculate; transverse dorsal pronotal carina antebasal, almost straight; lateral carina long, almost reaching apical margin of pronotum; elytra convex; greatest width at middle; humeri distinct; striae regular; elytral intervals flattened, wide; epipleuron distinct; pygidium concealed by elytra; femora weakly clavate; tibiae almost straight, without apical spurs; tarsomeres 1-3 with pulvilli on the underside; tarsomere 2 embracing tarsomere 3 laterally; tarsomere 3 bilobed; tarsal claws with large teeth at base.
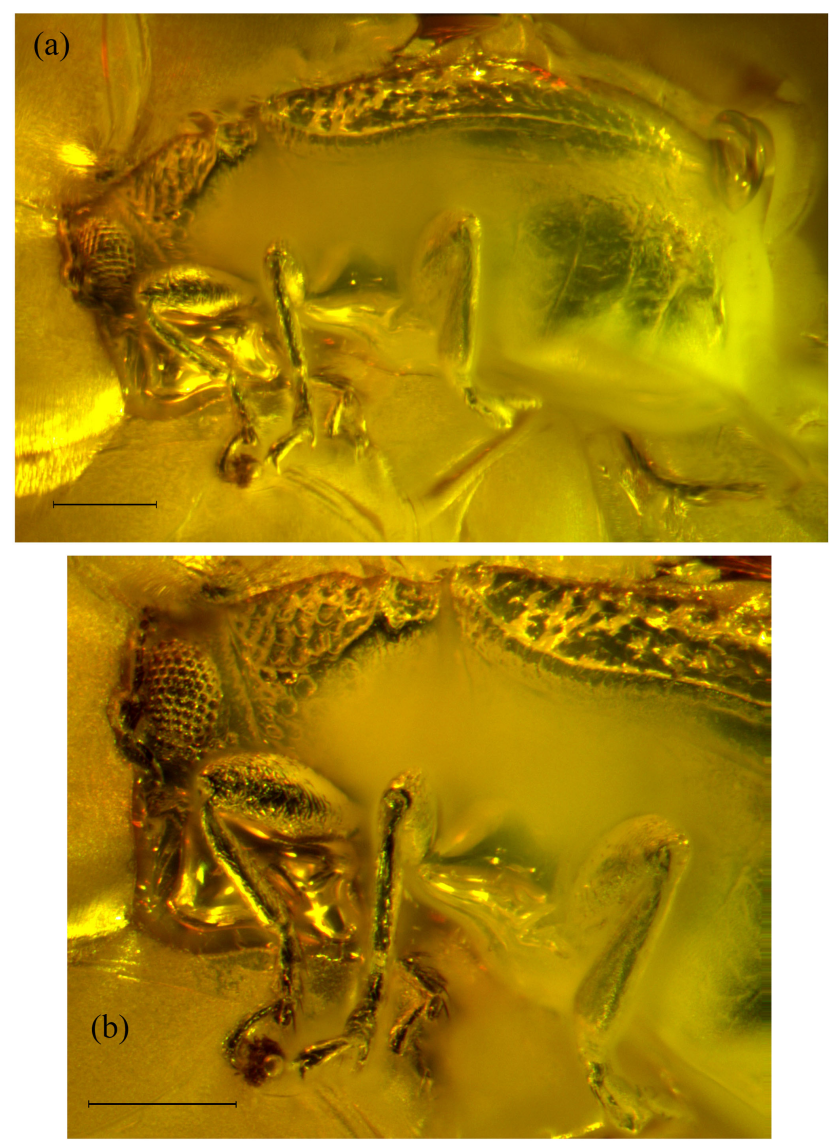

Figure 2. Eduardoxenus unicus gen. et sp. nov.: (a) body, lateral view; (b) first half of body. $\mathrm{Bar}=0.2 \mathrm{~mm}$.

Comparison: The new genus is similar to the genus Cyptoxenus Valentine, 1982 but differs from it in coarsely faceted eyes, antennomere 2 shorter than antennomere 1 and an almost glabrous body. It differs from the genus Valenfriesia Alonso-Zarazaga et Lyal, 1999 in the coarsely faceted eyes, almost straight transversal carina on the pronotum and distinct elytral humeri. It differs from the genus Neoxenus Valentine, 1999 in distinct lateral carina on the pronotum, coarsely faceted eyes and an almost straight transversal pronotal carina.

Remarks: The tarsomere 2 embraces tarsomere 3 laterally, labrum free, rostral pleurostomal sinus deep, pygidium present, tibiae lacking spurs, suggest placement of new genus in the family Anthribidae. The antennae inserted dorsally next to lower portion of eyes suggest placement in the subfamily Choraginae. Placement of this genus in the tribe Valenfriesiini is based on the pronotum with transverse carina, transverse pronotal carina antebasal and elytral intervals flattened. 

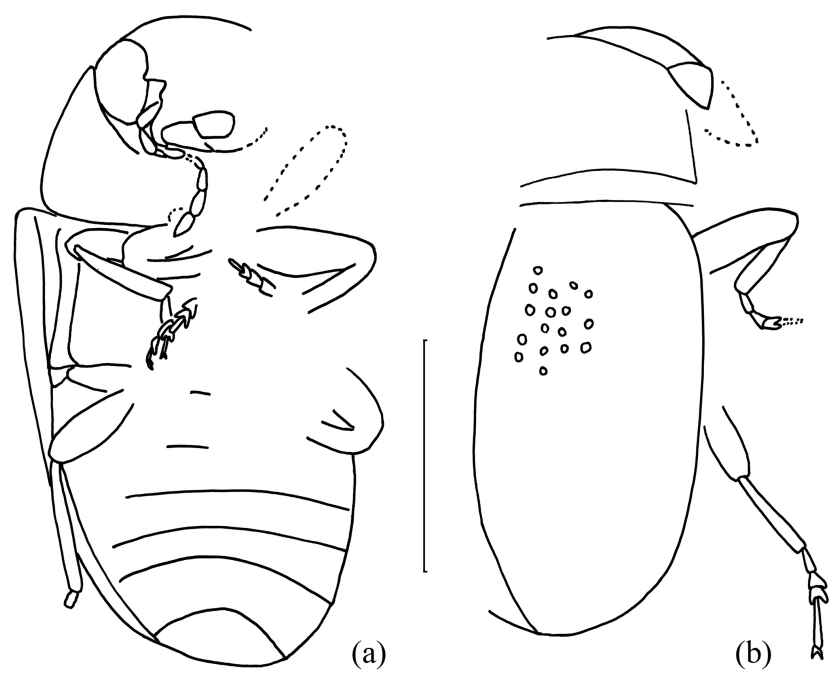

Figure 3. Eduardoxenus unicus gen. et sp. nov.: (a) contour of body, ventral view; (b) contour of body, dorsal view. $B a r=0.5 \mathrm{~mm}$.

\section{Eduardoxenus unicus sp. nov.}

Figs. 1-4.

Etymology: The specific epithet is from the Latin "unicus" (only, sole, single).

Holotype: SIZK K-25439, Klesov, Rovno amber, late Eocene.

\section{Type locality: Klesov.}

Description: Size: length of body (without rostrum), $1.4 \mathrm{~mm}$; length of rostrum, $0.2 \mathrm{~mm}$. Body, black, covered with sparse short hairs, appears silvery shiny due to presence of cavities between specimen and internal surface of its impression. Head: about 1.8 times as long as rostrum; rostrum moderately short, about 0.6 times as long as it is wide at the apex and middle, about 0.5 times as long as it is wide at the base, about 0.3 times as long as the pronotum, straight, densely punctate, without dorsal median carina; labrum free, almost wide-rectangular; mandibles large; rostral pleurostomal sinus deep; forehead wide, about 1.1 times as wide as the rostrum base width; eyes large, convex, about 1.4 times as long as they are wide, with 9-10 rows of facets perpendicular to maximum length; vertex weakly flattened, finely punctate; temples moderately short; antennal scrobes foveiform; antennae inserted next to the lower portion of eyes dorsally, not geniculate, moderately long, reach elytral humeri; antennomeres 1-8 conical; antennomere 1 about 2.5 times as long as it is wide; antennomere 2 about 1.9 times as long as it is wide, 0.7 times as long as and 0.9 times as wide as antennomere 1 ; antennomere 3 about 3.3 times as long as it is wide, 0.8 times as long as and 0.4 times as wide as antennomere 2; antennomere 4 about 2.4 times as long as it is wide, 0.6 times as long as and 0.8 times as wide as antennomere 3 ; antennomeres 3 and 4 subequal in length; antennomere 5 about 3.0 times as long as it is wide, 0.8 times as wide as antennomere 4 ; antennomeres 5 and 6 subequal in width; antennomere 6 about 2.5 times as long as it is wide, 0.8 times as long as antennomere 5; antennomere 8 about 2.0 times as long as it is wide; club not compact; antennomere 9 conical, about 1.8 times as long as it is wide, 1.4 times as long as and 1.6 times as wide as antennomere 8 ; antennomere 10 about 1.8 times as long as it is wide, 1.3 times as long as and 1.3 times as wide as antennomere 9; antennomere 11 drop-shaped, subequal in length and wide to antennomere 10. Pronotum: bell-shaped; disk weakly flattened, densely and rugosely punctate; transverse dorsal pronotal carina antebasal, almost straight; distance between transverse carina and base of pronotum 0.3 times as long as the pronotum; lateral carina long, almost reaching apical margin of pronotum. Mesonotum: scutellum small, almost semicircular, lays in the pentagonal scutellar groove. Elytra: distinctly convex, about 2.5 times as long as the pronotum; greatest width in the middle, lacking scutellar striole; elytron without tubercles; humeri weakly convex; striae regular and distinct; strial punctures quite small, rounded, sparse; elytral intervals flattened, wide, about 1.5-2.0 times as wide as the striae, sparsely and finely punctate; covered with sparse short thin sub-recumbent setae arranged in irregular rows on interstriae, slightly shorter and thinner setae on the borders of strial punctures; epipleuron distinct. Thorax: coarsely punctate; pre- and postcoxal portions of prosternum short; procoxal cavities narrowly separated; mesocoxal cavities rounded, narrowly separated; metanepisternum narrow, 9.8 times as long as it is wide in the middle. Metaventrite about 3.1 times as long as the metacoxal cavity length. Abdomen: convex, weakly flattened in middle; ventrite 1 about 1.6 times as long as the length of metacoxal cavities; ventrite 2 about 0.9 times as long as the length of ventrite 1 ; ventrite 3 about 0.9 times as long as the length of ventrite 2 ; ventrite 4 about 0.7 times as long as the length of ventrite 3 ; ventrite 5 about 1.8 times as long as the length of ventrite 4 ; pygidium concealed by elytra. Legs: long; pro- and mesocoxae round; metacoxae transverse; femora weakly clavate, without teeth; profemora about 2.2 times as long as they are wide; metafemora about 2.6 times as long as they are wide; tibiae almost straight, without apical spurs; protibiae about 6.9 times as long as they are wide in the middle; mesotibiae about 8.7 times as long as they are wide at the middle; metatibiae about 11.5 times as long as they are wide at the middle; tarsi long; tarsomeres 1-3 with pulvilli on the underside; tarsomeres 1-3 conical; tarsomere 2 embracing tarsomere 3 laterally; tarsomere 3 bilobed; tarsomere 4 short; tarsomere 5 elongate; tarsal claws divergent, with large teeth at base; protarsi: tarsomere 1 about 1.7 times as long as it is wide; tarsomere 2 about 1.4 times as long as it is wide, 1.1 times as long as and 1.3 times as wide as tarsomere 1; tarsomere 3 about 1.3 times as long as it is wide, 0.6 times 

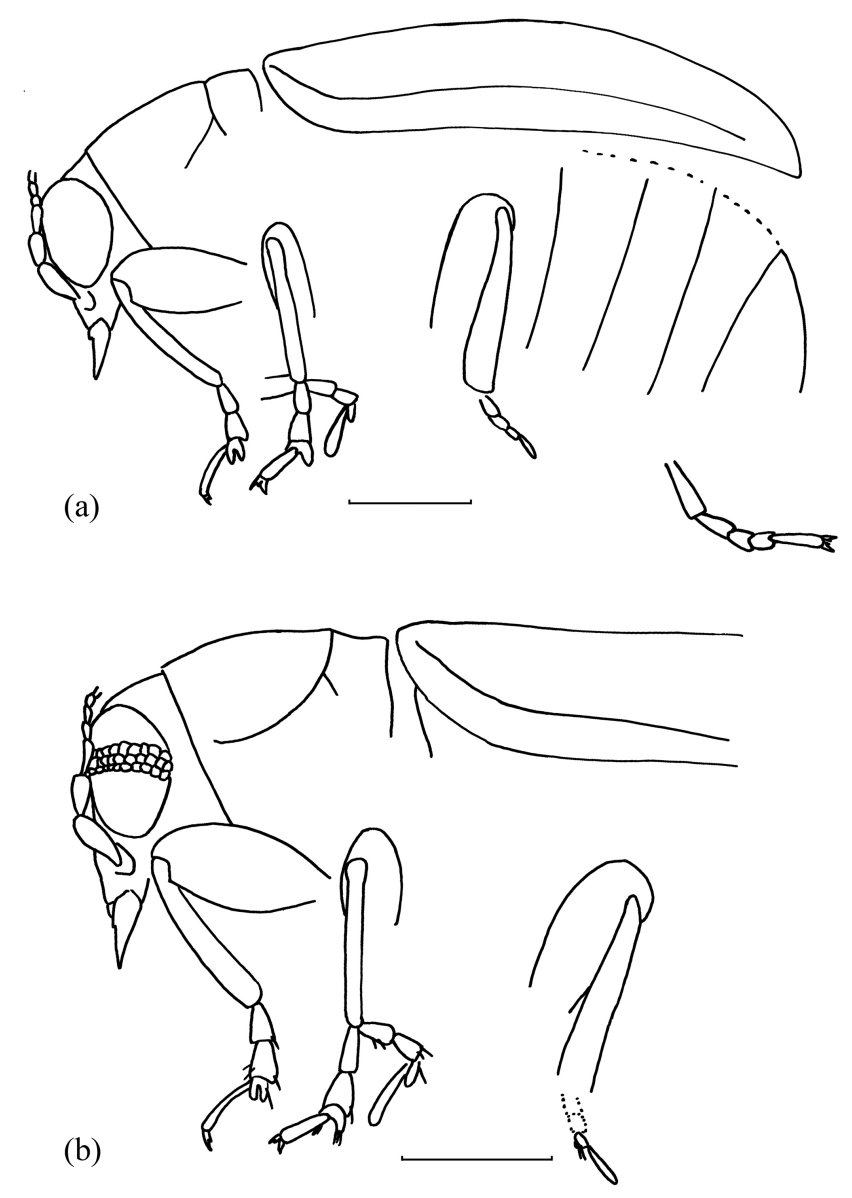

Figure 4. Eduardoxenus unicus gen. et sp. nov.: (a) contour of body, lateral view; (b) contour of first half of body. Bar $=0.2 \mathrm{~mm}$.

as long as and 0.7 times as wide as tarsomere 2; tarsomere 5 about 7.0 times as long as it is wide, 2.6 times as long as and 0.5 times as wide as tarsomere 3 ; mesotarsi: tarsomere 1 about 2.2 times as long as it is wide; tarsomere 2 about 1.6 times as long as it is wide, 1.1 times as long as and 1.5 times as wide as tarsomere 1 ; tarsomere 3 about 1.1 times as long as it is wide, 0.6 times as long as and 0.9 times as wide as tarsomere 2; tarsomere 5 about 4.8 times as long as it is wide, 2.1 times as long as and 0.5 times as wide as tarsomere 3.

\section{Discussion}

The family Anthribidae is not known from Palaeocene deposits but is well represented in the Eocene faunas. The American Eocene faunas of the Green River (early-midEocene) and Florissant (terminal Eocene) are largely similar and contain the tribes Cratoparini, Tropiderini, Anthribini, Discotenini, Ecelonerini and Zygaenodini (Legalov, 2015, 2018; Kirejtshuk et al., 2018). The tribes Allandrini and Zygaenodini with predominance of the genus Glaesotropis
Gratshev et Zherikhin, 1995 (Zygaenodini) are presented in the Baltic and Rovno ambers (Gratshev and Zherikhin, 1995; Gratshev and Perkovsky, 2008; Legalov, 2012, 2013a, 2015; Kirejtshuk et al., 2018). A total of 18 species from the eight genera of the tribes Cratoparini, Platystomini, Eugonini, Piesocorynini, Choragini and Valenfriesiini were described from Miocene Dominican and Mexican ambers (Poinar Jr. and Legalov, 2016). The Paleogene representatives of the subfamily Choraginae were known from the Eocene of the USA (Green River: Scudder, 1890) and the Oligocene of Germany (Rott: Heyden and Heyden, 1866). The species from tribes Choragini and Valenfriesiini were found in the Dominican amber. The new genus is the oldest finding of the tribe Valenfriesiini in fossil state and the first record of the Choraginae from Eocene ambers.

Valenfriesiini are distributed almost exclusively in the tropics, more abundant on Saint Helena and the Antilles, and known in Holarctic region only from Japan, Kuril Islands, central Taiwan and Texas. Most of the records of Valenfriesiini are associated with non-Holarctic vegetation. The tropical elements in the late Eocene floras of Volyn' Elevation (of the same age as the Rovno amber forest) are distinctly poorer than we previously supposed (Perkovsky et al., 2010), although they are more abundant than in the Baltic amber forest (Sokoloff et al., 2018). In the Rovno amber fauna Valenfriesiini represents the fourth taxon of a suprageneric rank, which is also unknown from the Baltic amber fauna (the rest are the extinct crabronid tribe Protomicroidini, figitid subfamily Eucoilinae Thomson, 1862 and Capniidae stoneflies; Perkovsky et al., 2010; Buffington et al., 2014). At the same time, the taxa of the generic rank unknown from the Baltic amber are quite abundant: only Hymenoptera is represented by 19 genera (Perkovsky, 2018), and this number will increase along with investigation of the Rovno fauna. We can assume that Valenfriesiini belong to the group of taxa for which the southern coast of Subparathetys (Jałoszyński and Perkovsky, 2016) was the northernmost boundary of their geographic range, e.g. the ant genus Fallomyrma Dlussky et Radchenko, 2006, known from the Rovno (type species and three other species), Bitterfeld and Scandinavian ambers (type species) (Perkovsky, 2011; Radchenko and Dlussky, 2018). The climate of the southern coast of Subparathetys was much warmer than that of the Baltic amber forest (Wolfe et al., 2016; Mänd et al., 2018), which determined a much higher share of the tropical elements in the fauna (Perkovsky, 2013, 2016, 2017). Some tropical elements from Bitterfeld and Rovno amber, e.g. Thallisellini (Erotylidae: Languriinae), the Litochropus genus group (Phalacridae) (Lyubarsky and Perkovsky, 2016, 2017) and the extremely thermophilic (Vladimir Ivanov, personal communication, 2013) trichopteran genus Leptocerus Leach, 1815 (Ivanov et al., 2016) are unknown from Baltic amber. 
Data availability. All material included in the paper is accessible in the Schmalhausen Institute of Zoology of the National Academy of Sciences of Ukraine, Kiev, and all data are included in the description.

Author contributions. AAL produced the figures. VYN produced the photos. AAL, VYN, and EEP prepared the paper and contributed to the editing.

Competing interests. The authors declare that they have no conflict of interest.

Acknowledgements. We are grateful to Boris A. Korotyaev (Russia: St. Petersburg) and Pol Limbourg (Belgium: Brussels) for the opportunity to study comparative material of the family Anthribidae deposited in the Zoological Institute of the Russian Academy of Sciences and the Institut royal des Sciences naturelles de Belgique, to Alexandr P. Rasnitsyn (Russia: Moscow) for discussing the paper, and to Anatoly P. Vlaskin (Ukraine: Rovno) for polishing the piece of amber.

Edited by: Torsten Scheyer

Reviewed by: Leonid Friedman and one anonymous referee

\section{References}

Alonso-Zarazaga, M. A. and Lyal, C. H. C.: A world catalogue of families and genera of Curculionoidea (Insecta: Coleoptera), Entomopraxis: Barcelona, Spain, 1999.

Belles, X. and Perkovsky, E. E.: New Data on the Genus Sucinoptinus (Coleoptera, Ptinidae) from Rovno amber, Vestn. Zool., 50, 17-22, 2016.

Billberg, G. J.: Enumeratio Insectorum in Musaeo Gust. Joh. Bill berg. Stockholm: Typis Gadelianis, 1820.

Buffington, M. L., Perkovsky, E. E., and Brady, S. G.: The description of Rovnoeucoila tympanomorpha Buffington and Perkovsky, a new genus and species of fossil Eucoiline, with observations on the asynchronous evolution of Diglyphosematini (Hymenoptera: Figitidae: Eucoilinae), Proc. Entomol. Soc. Washington, 116, 243-254, https://doi.org/10.4289/0013-8797.116.3.243, 2014.

Dlussky, G. M. and Radchenko, A.: Fallomyrma gen. nov., a new myrmicine ant genus (Hymenoptera: Formicidae) from the Late Eocene European amber, Ann. Zool., 56, 153-157, 2006.

Gratshev, V. G. and Perkovsky, E. E.: New species of the genus Glaesotropis (Insecta: Coleoptera: Anthribidae) from Rovno amber, Paleontol. J., 42, 60-63, 2008.

Gratshev, V. G. and Zherikhin, V. V.: A new anthribid genus from the Baltic amber (Insecta: Coleoptera: Anthribidae), Mitt. Geol.Paläontol. Inst. Hamburg, 78, 149-157, 1995.

Heyden, C. and Heyden, L.: Käfer und Polypen aus der Braunkohle des Siebengebirges, Palaeontographica, 15, 131-156, 1866.

Hieke, F. and Pietrzeniuk, E.: Die Bernstein-Käfer des Museums für Naturkunde, Berlin (Insecta, Coleoptera), Mitt. Zool. Museum Berlin, 60, 297-326, 1984.
Ivanov, V. D., Melnitsky, S. I., and Perkovsky, E. E.: Caddisflies from Cenozoic resins of Europe, Paleontol. J., 50, 485-493, https://doi.org/10.1134/S0031030116050063, 2016

Jałoszyński, P. and Perkovsky, E.: Diversity of Scydmaeninae (Coleoptera: Staphylinidae) in Upper Eocene Rovno amber, Zootaxa, 4157, 1-85, https://doi.org/10.11646/zootaxa.4157.1.1, 2016.

Kirby, W.: A century of Insects, including several new genera described from his cabinet, Trans. Linn. Soc. London, 12, 375-453, 1819.

Kirejtshuk, A. G., Ponomarenko, A. G., and Zherikhin, V. V.: Catalogue of fossil Coleoptera. Beetles (Coleoptera) and Coleopterologists, Zoological Institute of the Russian Academy of Sciences, St. Petersburg, updated June 2018, available at: https: //www.zin.ru/Animalia/Coleoptera/rus/paleosys.htm, last access: 5 June 2018.

Lawrence, J. F., Beutel, R. G., Leschen, R. A. B., and Slipinski, S. A.: Chapter 2. Glossary of Morphological Terms, Handbook of Zoology, Arthropoda: Insecta, Tb. 40: Coleoptera (Beetles), Vol. 2: Morphology and Systematics (Elateroidea, Bostrichformia, Cucujiformia partim), 9-20, 2010.

Leach, W. E.: Entomology, The Edinburgh Encyclopaedia, Edinburg: Baldwin, 9, 57-172, 1815.

Legalov, A. A.: First record of Anthribid beetles from the Jurassic of Kazakhstan (Coleoptera: Anthribidae), Paleontol. J., 45, 629633, https://doi.org/10.1134/S0031030111060074, 2011.

Legalov, A. A.: New curculionoid beetles (Coleoptera: Curculionoidea) from the Baltic amber, Paleontol. J., 46, 262-272, https://doi.org/10.1134/S0031030112030094, 2012.

Legalov, A. A.: New and little known weevils (Coleoptera: Curculionoidea) from the Paleogene and Neogene, Hist. Biol., 25 , 59-80, https://doi.org/10.1080/08912963.2012.692681, 2013 a.

Legalov, A. A.: Review of the family Anthribidae (Coleoptera) from the Jurassic of Karatau: subfamily Protoscelinae. Genus Protoscelis Medvedev, Paleontol. J., 47, 292-302, https://doi.org/10.1134/S0031030113030064, 2013b.

Legalov, A. A.: Fossil weevils (Coleoptera, Obrienioidea, Curculionoidea) from Mesozoic and Cainozoic, Paleontol. J., 49, 1442-1513, https://doi.org/10.1134/S0031030115130067, 2015.

Legalov, A. A.: New weevils (Coleoptera, Curculionoidea) from the Eocene of the Green River, United States: Part 1, Paleontol. J., 52, 294-302, https://doi.org/10.1134/S0031030118030061, 2018.

Lyubarsky, G. Yu. and Perkovsky, E. E.: A new genus, Neolitochropus (Coleoptera: Cucujoidea: Phalacridae), from the Upper Eocene Bitterfeld amber, Russian Entomol. J., 25, 249-253, 2016.

Lyubarsky, G. Yu. and Perkovsky, E. E.: Serramorphus, a new genus of Erotylidae from Eocene amber (Coleoptera: Clavicornia) from Late Eocene Bitterfeldian amber, Russian Entomol. J., 26, 37-40, 2017.

Louw, S.: Systematics of the Urodontidae (Coleoptera: Curculionoidea) of southern Africa, Entomology Mem. Dep. Agric. Repub. S. Afr., 87, Parow East: CTP Book Printers, 1-92, 1993.

Mänd, K., Muehlenbachs, K., McKellar, R. C., Wolfe, A. P., and Konhauser, K.: Distinct origins for Rovno and Baltic ambers: Evidence from carbon and hydrogen stable isotopes, Palaeogeogr. Palaeocl., 505, 265-273, https://doi.org/10.1016/j.palaeo.2018.06.004, 2018. 
Mermudes, J. R. M. and Leschen, R. A. B.: 3.2 Anthribidae Billberg, 1820, Handbook of Zoology, Arthropoda: Insecta, Tb. 40: Coleoptera (Beetles), Vol. 3: Morphology and Systematics (Phytophaga), 309-315, 2014.

Nadein, K. S. and Perkovsky, E. E.: A new tribe of Galerucinae leaf beetle (Insecta: Coleoptera: Chrysomelidae) from the Upper Cretaceous Taimyr amber, Cretaceous Res., 84, 97-106, https://doi.org/10.1016/j.cretres.2017.10.023, 2018.

Perkovsky, E. E.: Syninclusions of the Eocene winter ant Prenolepis henshei (Hymenoptera: Formicidae) and Germaraphis aphids (Hemiptera: Eriosomatidae) in Late Eocene Baltic and Rovno amber: some implications, Russian Entomol. J., 20, 303-313, 2011.

Perkovsky, E. E.: Eohelea sinuosa (Meunier, 1904) (Diptera, Ceratopogonidae) in Late Eocene ambers of Europe, Paleontol. J., 47, 503-512, https://doi.org/10.1134/S0031030113040163, 2013.

Perkovsky, E. E.: Tropical and Holarctic ants in Late Eocene ambers, Vestn. Zool., 50, 111-122, 2016.

Perkovsky, E. E.: Comparison of biting midges of the Early Eocene Cambay amber (India) and Late Eocene European Ambers supports the independent origin of European ambers, Vestn. Zool., 51, 275-284, 2017.

Perkovsky, E. E.: Only a half of species of Hymenoptera in Rovno amber is common with Baltic amber, Vestn. Zool., 52, in press, 2018.

Perkovsky, E. E., Zosimovich, V. Y., and Vlaskin, A. P.: Rovno Amber, in: Biodiversity of fossils in amber from the major world deposits, edited by: Penney, D., Siri Scientific Press, Manchester, 116-136, 2010.

Poinar Jr., G. and Legalov, A. A.: New Anthribidae (Coleoptera: Curculionoidea) in Dominican and Mexican ambers, Palaeontol. Electron., 19, 1-38, https://doi.org/10.26879/635, 2016.
Radchenko, A. G. and Dlussky, G. M.: Ants of the genus Fallomyrma Dlussky et Radchenko (Hymenoptera, Formicidae, Myrmicinae) from the Late Eocene European ambers, Paleontol. J., 52, 155-163, https://doi.org/10.1134/S0031030118020107, 2018.

Rheinheimer, J.: Illustrierter Katalog und Bibliographie der Anthribidae der Welt (Insecta: Coleoptera), Mitt. Entomol. Ver. Stuttgart, 39, 1-288, 2004.

Scudder, S. H.: The Tertiary insects of North America, US Geol. Surv. Terr., 13, 1-734, 1890.

Seyfullah, L. J,, Beimforde, Ch., Dal Corso, J., Perrichot, V., Rikkinen J., and Schmidt, A. R.: Production and preservation of resins - past and present, Biol. Rev., 93, 1684-1714, https://doi.org/10.1111/brv.12414, 2018.

Sokoloff, D. D., Ignatov, M. S., Remizowa, M. V., Nuraliev, M. S., Blagoderov, V., Garbout, A., and Perkovsky, E. E.: A male flower of Prunus s.l. (Rosaceae) from Eocene Rovno amber (Ukraine), J. Plant Res., 1-19, https://doi.org/10.1007/s10265-018-1057-2, 2018.

Soriano, C., Gratshev, V. G., and Delclos, X.: New Early Cretaceous weevils (Insecta, Coleoptera, Curculionoidea) from El Montsec, Spain, Cretac. Res., 27, 555-564, 2006.

Valentine, B. D.: Anew endemic genus of Anthribid weevil from Jamaica (Anthribidae: Araecerini), Col. Bull., 36, 197-199, 1982.

Valentine, B. D.: A review of Nearctic and some related Anthribidae (Coleoptera), Insecta Mundi, 12, 251-296, 1999.

Wolfe, A. P., McKellar, R. C., Tappert, R., Sodhi, R. N. S., and Muehlenbachs, K.: Bitterfeld amber is not Baltic amber: Three geochemical tests and further constraints on the botanical affinities of succinite, Rev. Palaeobot. Palynol., 225, 21-32, 2016.

Zherikhin, V. V.: Suborder Polyphaga, Tr. Paleontol. Inst. Akad. Nauk SSSR (Mesozoic Insects and Ostracodes of Asia), 252, 20 37, 1993. 